\title{
7-Endo selenocyclization reactions on chiral 3-prenyl and 3- cinnamyl-2-hydroxymethylperhydro-1,3-benzoxazine derivatives. A way to enantiopure 1,4-oxazepanes
}

\author{
Javier Nieto,* Celia Andrés* and Alfonso Pérez-Encabo
}

Instituto CINQUIMA and Departamento de Química Orgánica, Facultad de Ciencias, Universidad de Valladolid, Paseo de Belén, 7, 47011 Valladolid, Spain. E-mail: javiernr@qo.uva.es

Enantiopure 1,4-oxazepanes derivatives have been prepared by selenocyclofunctionalization of chiral 3prenyl- and 3-cinnamyl-2-hydroxymethyl-substituted perhydro-1,3-benzoxazine derivatives. The 7-endocyclization occurs in high yields and diastereoselection. The regio and stereochemistry of the cyclization products was dependent of the substitution pattern of the double bond, the nature of the hydroxyl group and the experimental conditions.

\section{Introduction}

1,4-Oxazepanes, ${ }^{1}$ seven-membered heterocyclic compounds containing nitrogen and oxygen analogues to morpholines, compose an important class of heterocyclic compounds from both synthetic and biological points of view. 1,4-Oxazepane derivatives exhibit a wide range of biological activities, including antifungal, ${ }^{2}$ antihistaminic, ${ }^{3}$ anticonvulsant, ${ }^{4}$ analgesic, ${ }^{5}$ antiviral, ${ }^{6}$ antihypertensive and anti-congestive heart failure, ${ }^{7}$ or they are potent apoptotic agents. ${ }^{8}$ 1,4-Oxazepanes have also been studied for their ability to inhibit a broad range of glycosidase enzymes, ${ }^{9}$ specific kinases ${ }^{10}$ and nitric oxide synthases, ${ }^{11}$ and behave as selective dopamine $D_{4}$ receptor ligands. ${ }^{12}$ 1,4Oxazepanes are also important components of skeleton of interesting natural products such as the neurotoxin batrachotoxin. ${ }^{13}$ In addition, chiral 1,4-oxazepane-5,7-diones are valuable chiral templates for stereoselective synthesis. ${ }^{14}$

Despite their importance, very few syntheses of chiral substituted 1,4-oxazepanes have been reported. ${ }^{15}$

The electrophile-mediated cyclofunctionalization of alkenes containing and internal nucleophile ${ }^{16}$ is an useful cyclization reaction for the preparation of heterocyclic compounds and seven-membered compounds have been synthesized in good yields in this way by a proper choice of the electrophilic reagents and the substituents at the double bond. ${ }^{15 h, 17,18}$ In a previous paper, we have described the regio- and diastereoselective methoxyselenenylation of chiral 2vinyl $^{19}$ and 3-allylperhydro-1,3-benzoxazines ${ }^{20}$ and the synthesis of enantiopure morpholine derivatives by selenocyclofunctionalization ${ }^{21,22}$ of chiral 3-allyl-2-hydroxymethyl substituted perhydro-1,3-benzoxazine derivatives. ${ }^{23}$ In most cases, 3-allyl-2-hydroxymethylperhydro-1,3benzoxazine derivatives cyclized in an 6-exo mode with total regioselectivity to the morpholine ring in the presence of benzeneselenenyl chloride. However, perhydro-1,3-benzoxazines with two methyl substituents at the terminal position of the double bond lead to a mixture of 6-exo and 7-endo cyclization products and it is possible to obtain, under certain conditions, the 7-endo products in a regioselective way (in agreement with Markovnikov's rule). For instance, 
treatment of the 3-prenylperhydro-1,3-benzoxazine derivative 10a bearing a secondary hydroxyl group in $\mathrm{C}-2$ with $\mathrm{PhSeCl}$ in $\mathrm{CH}_{2} \mathrm{Cl}_{2}$ at $-78{ }^{\circ} \mathrm{C}$ in the presence of $\mathrm{SnCl}_{4}$ mainly furnished the 7-endo product 11a together with only a 7\% of the 6-exo product $\mathbf{1 4 a} .^{21}$

Our interest in preparation of enantiopure 1,4-oxazepanes has prompted us to study the regio and stereoselective selenocyclofunctionalization of 3-prenyl and 3-cinnamyl-2hydroxymethylperhydro-1,3-benzoxazine derivatives promoted by benzeneselenenyl chloride. We envisioned that a phenyl substituent located at the terminal position of the double bond could greatly improve the endo-regioselectivity. Herein, we report our results in detail.

\section{Results and discussion}

The starting chiral perhydro-1,3-benzoxazines $\mathbf{1 0 b}$ and $\mathbf{1 0 g}-\mathbf{k}$ were prepared as single diastereomers, in good to excellent yields, as summarized in Scheme 1.

Treatment of ketone $\mathbf{1}^{24}$ with sodium borohydride in methanol at $-10^{\circ} \mathrm{C}$ afforded nearly quantitative the alcohol $\mathbf{1 0 b}$. The primary alcohol $10 \mathrm{~g}$ was obtained by condensation of amino alcohol $2^{25}$ with glycolaldehyde dimer in a mixture of $\mathrm{CH}_{2} \mathrm{Cl}_{2}$-toluene at reflux. Alkylation of 2benzoylperhydrobenzoxazine $\mathbf{3}^{24}$ with cinnamyl bromide and potassium carbonate in refluxing acetonitrile afforded ketone 4 , which was transformed into the alcohol $10 \mathrm{~h}$ by reduction of the carbonyl group with sodium borohydride. A similar reduction of ketone $\mathbf{6}$ obtained by condensation of aminomenthol derivative $5^{26}$ with phenylgyoxal in toluene at reflux, afforded alcohol 10i. Carbinol 10j was obtained by addition of methylmagnesium iodide to the ester $\mathbf{8}$, which was obtained by alkylation of benzoxazine $7^{24}$ with cinnamyl bromide. Lastly, alcohol $10 \mathrm{k}$, epimer of $10 \mathrm{~h}$, was prepared by addition of phenylmagnesium bromide to the aldehyde $\mathbf{9}^{27}$ in diethyl ether at $-10{ }^{\circ} \mathrm{C}$. As expected, the reduction of ketones 1,4 and 6 to alcohols $10 \mathrm{~b}, 10 \mathrm{~h}$ and 10i with sodium borohydride proceeded with excellent diastereomeric excesses (de > 92\%). ${ }^{28}$ The diastereoselectivity in the addition of the phenyl-Grignard reagent to aldehyde 9 is lightly lower $(88 \%$ de). After purification by flash chromatography and/or recrystallization, all these compounds were obtained as single diastereomers and their absolute configuration in the new created stereocentre was assigned as $S$ for alcohols $10 \mathbf{b}, 10 \mathbf{h}$ and $10 \mathbf{i}$ and $R$ for alcohol $10 \mathrm{k}$ in agreement with Eliel's reports. ${ }^{28}$

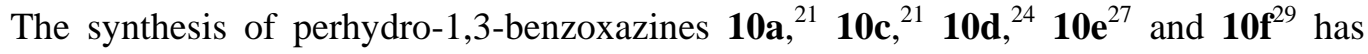
been previously described.

Selenocyclofunctionalization of alcohols 10a-k was tested under different reaction conditions and with different selenium reagents and additives. After extensive experimentation, we found that the cyclic endo-products were obtained in moderate to good yields and stereoselection under two different reaction conditions using benzeneselenenyl chloride as electrophile, in $\mathrm{CH}_{2} \mathrm{Cl}_{2}$ in the presence of $\mathrm{SnCl}_{4}$ at $-78{ }^{\circ} \mathrm{C}$ or in acetonitrile at room temperature. The results are summarized in Table 1.

All unsaturated alcohols furnished the selenocyclization products in excellent chemical yield, with the exception of alcohol 10f. Nevertheless, the behaviour of 3-cinnamyl derivatives 10e-k differs from that show by the 3-prenyl substituted perhydro-1,3-benzoxazines 10a-d. The selenocyclofuntionalization of cinnamyl derivatives 10e-k turned out with very high or total endo-regioselectivity (entries 9-19 in Table 1), only a 5\% of exo product $\mathbf{1 3 \mathbf { j }}$ was detected in the 
cyclization of the tertiary alcohol $\mathbf{1 0 j}$ (entry 18). By contrast, the regioselectivity in the cyclization of prenyl derivatives 10a-d was dependent on both the reaction conditions and the substitution about the hydroxyl group (entries 1-8).
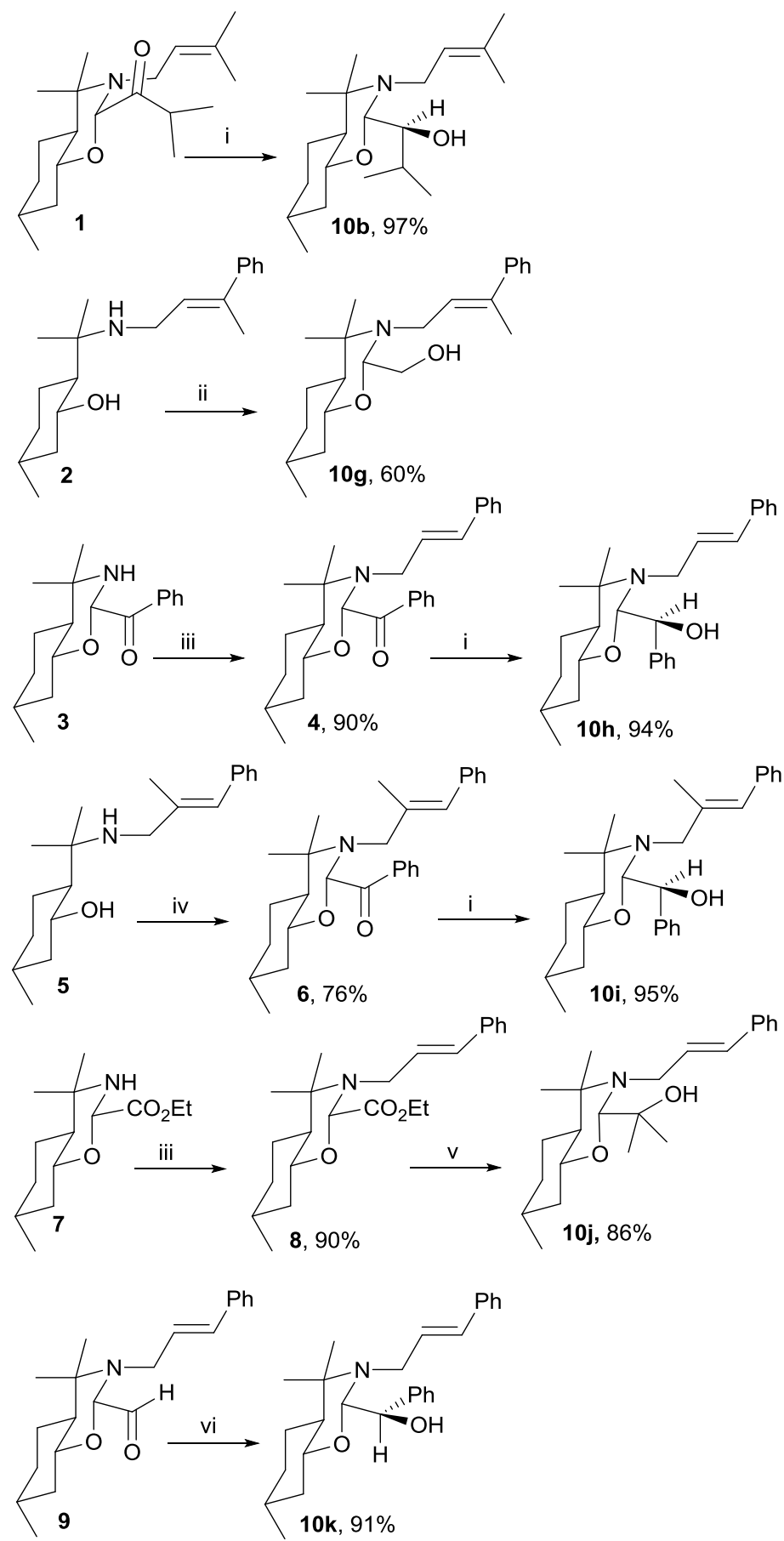

Scheme 1 Synthesis of perhydrobenzoxazines $\mathbf{1 0 b}$ and $\mathbf{1 0 g}$-h. Reagents and conditions: (i) $\mathrm{NaBH}_{4}$, EtOH, $-10{ }^{\circ} \mathrm{C}$ (ii) Glycolaldehyde dimer, toluene, $\mathrm{CH}_{2} \mathrm{Cl}_{2}$, reflux (iii) Cinnamyl bromide, $\mathrm{K}_{2} \mathrm{CO}_{3}$,

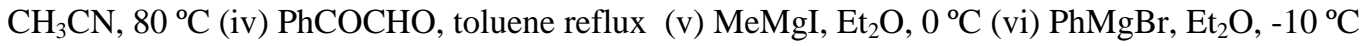




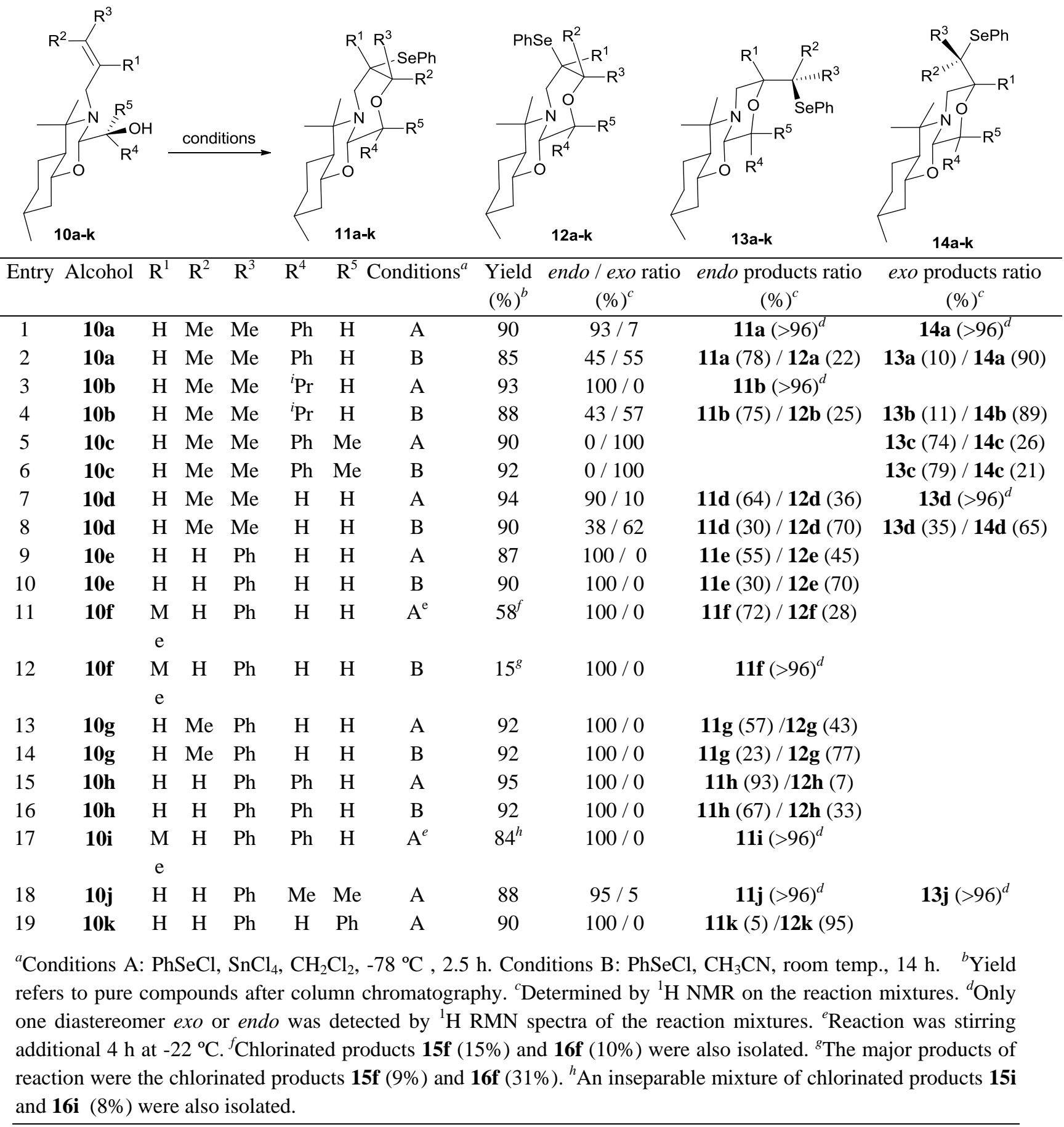

Excellent yields and levels of regioselectivity in favour of endo products are obtained in the cyclization of secondary alcohols $\mathbf{1 0 a}$ and $\mathbf{1 0 b}$ in $\mathrm{CH}_{2} \mathrm{Cl}_{2}$ in the presence of $\mathrm{PhSeCl}$ and $\mathrm{SnCl}_{4}$ at $-78^{\circ} \mathrm{C}$ (entries 1 and 3), whereas the regioselectivity in cyclization of primary alcohol 10d in the same conditions slightly decreased (entry 7). The regioselectivity in the cyclization of primary and secondary alcohols in acetonitrile at room temperature was very poor (entries 2, 3 and 8). Surprisingly, the tertiary alcohol 10c cyclized with total regioselectivity, but, in favour of exo products in all tested reaction conditions (entries 5 and 6). ${ }^{21}$ This effect (anti- 
Markovnicov's rule) due to the increase of steric hindrance on increasing the substitution about the carbinol has been previously described. ${ }^{30}$ The differences in the behaviour of the cinnamyl and the prenyl derivatives can be explained by the greater stabilizing effect by the aromatic ring of the developing positive charge in cinnamyl derivatives, favouring the endo process. On the other hand, the double substitution at the terminal double bond in prenyl derivatives can have a negative effect due to the increase of steric hindrance which disfavoured the formation of 7 membered rings. ${ }^{17}$

Interesting, the diastereoselectivity in the endo path-way was dependent on both the reaction conditions and the nature of the hydroxyl group. Nevertheless, the nature of the substituents at the double bond has less influence. The selenocyclofunctionalization of secondary alcohols $\mathbf{1 0 a}, \mathbf{b}, \mathbf{h , i}, \mathbf{i}, \mathbf{k}$ and the tertiary alcohol $\mathbf{1 0 j}$ with $\mathrm{PhSeCl}$ in $\mathrm{CH}_{2} \mathrm{Cl}_{2}$ at $-78{ }^{\circ} \mathrm{C}$ in the presence of $\mathrm{SnCl}_{4}$ (method A, entries 1, 3, 15 and 17-19) lead to the oxazepines 11a,b,h-k with very high or total diastereoselectivity. However, when cyclization was carried out in acetonitrile at room temperature (method B, entries 2, 4 and 16) the diastereoselectivity decrease considerably.

With the purpose to evaluate the influence that the chiral centre at the carbon bearing the hydroxyl group exerts in the asymmetric induction we tested the behaviour of epimeric alcohols 10h and 10k (entries 15 and 19). Both selenocyclofunctionalizations turned out with excellent diastereoselectivity but the facial diastereoselection was reversed and oxazepanes 11h and 12k were obtained respectively as major products. This result seems to suggest that the chiral centre at the carbon bearing the hydroxyl group is the main responsible for the high asymmetric induction observed. Nevertheless, the very high diastereoselectivity obtained in cyclization of the tertiary alcohol $\mathbf{1 0 j}$ (entry 18 ) without a chiral centre at the carbon bearing the hydroxyl group can only be due to the asymmetric induction exerted by the benzoxazine moiety.

The diastereselection in the reaction of compounds 10d-g, with a primary hydroxyl group, with $\mathrm{PhSeCl}$ in $\mathrm{CH}_{2} \mathrm{Cl}_{2}$ at $-78{ }^{\circ} \mathrm{C}$ in the presence of $\mathrm{SnCl}_{4}$ was lower than that obtained for the secondary alcohols (compare entries 7, 9 and 11 versus 1, 15 and 17). Interesting, the selenocyclization of the primary alcohols turned out with reverse stereoselectivity when $\mathrm{PhSeCl}$ in acetonitrile at room temperature was used (compare entries 7, 9, 11 and 13 versus 8, 10, 12 and 14). Although the diastereoselectivity remained moderate it was better than that obtained in $\mathrm{CH}_{2} \mathrm{Cl}_{2}$ at $-78{ }^{\circ} \mathrm{C}$ in the presence of $\mathrm{SnCl}_{4}$. Alcohol $10 \mathrm{f}$ with a methyl substituent at the inner carbon of the double bond is an exception since it furnished a single diastereoisomer 12f, although, in low yield (entry 12). In this case, the major products of reaction were the chlorinated products $\mathbf{1 5 f}$ and $\mathbf{1 6 f}$ that were isolated in $9 \%$ and $31 \%$ yield respectively. The observed result might be explained assuming an initial chloro phenylselenylation of the double bond followed by activation of the selenium moiety as a leaving group by transformation of the selenide into selenonium ion by excess of $\mathrm{PhSeCl}$ and intramolecular nucleophilic displacement (Scheme 3). ${ }^{31}$ This intramolecular substitution occurs with inversion of configuration at the carbon atom bearing the selenium atom. ${ }^{32}$ The products $\mathbf{1 5 f}$ and $\mathbf{1 6 f}$ were also isolated in $15 \%$ and $10 \%$ respectively when selenocyclization was carried out with $\mathrm{PhSeCl}$ in $\mathrm{CH}_{2} \mathrm{Cl}_{2}$ at $-78{ }^{\circ} \mathrm{C}$ in the presence of $\mathrm{SnCl}_{4}$.

Cyclization of secondary alcohol 10i with a methyl substituent at the inner carbon of the double bond also furnished a mixture of two similar chlorinated products, but only in $8 \%$ chemical yield, together with the oxazepine $11 \mathbf{i}$ (entry 17). 


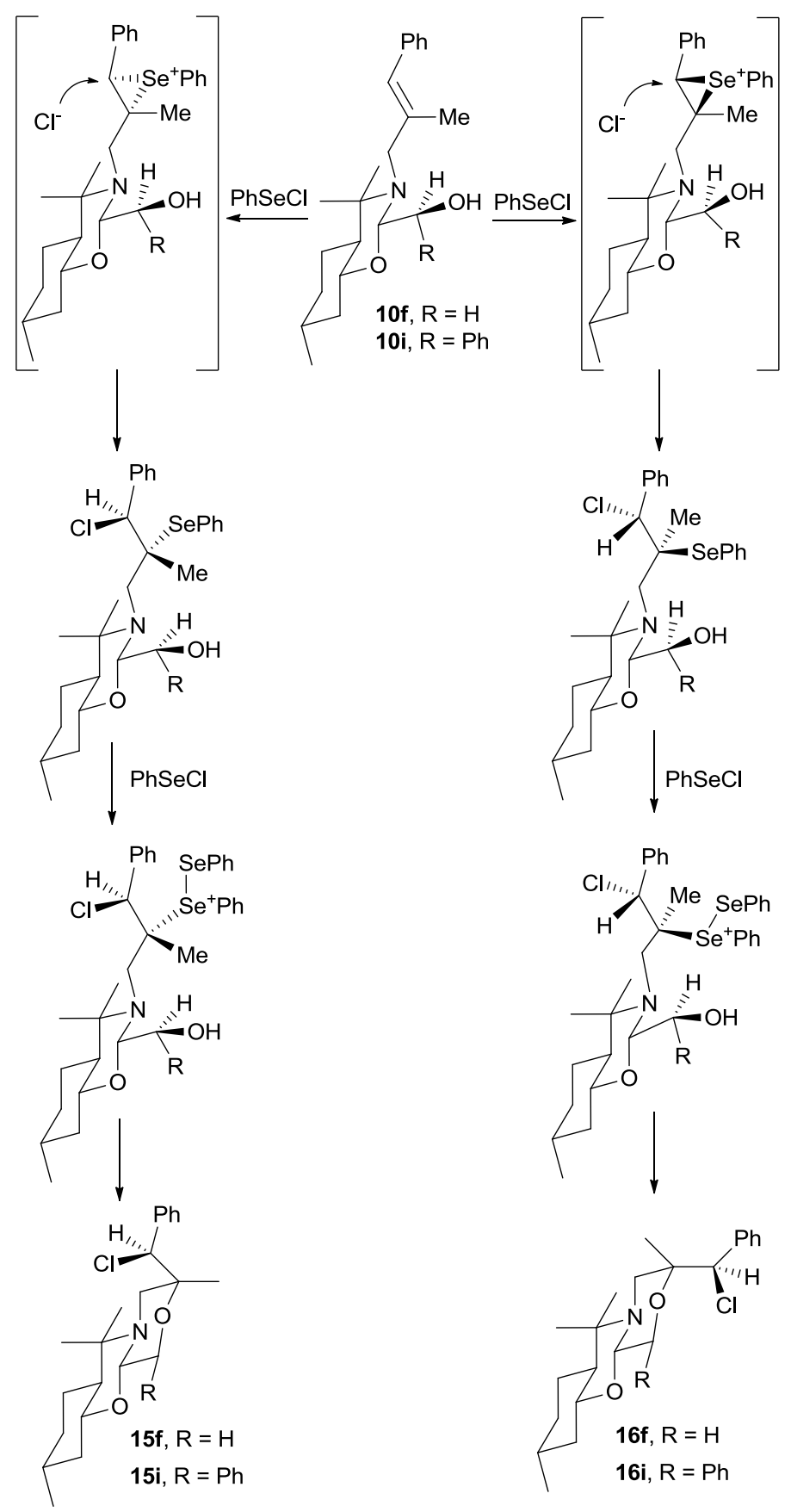

Scheme 2. Formation of clorinated products 15f, 15i, 16f, and 16i.

The diastereoisomers formed in each reaction were isolated and purified by flash chromatography and/or crystallization, and their structure was determined on the basis of ${ }^{1} \mathrm{H}$ and ${ }^{13} \mathrm{C}$ NMR spectra. The regiochemistry was also confirmed by reductive deselenenylation with triphenyltin hydride in the presence of catalytic amounts of AIBN in refluxing toluene (Scheme 3). ${ }^{33}$ As expected, deselenylation of diastereomeric oxazepines $\mathbf{1 1 b}$ and $\mathbf{1 2 b}$ lead to the same product 17b. Deselenylation of the inseparable mixture of 11e and 12e allowed for the isolation of pure oxazepines 17e and 18e. On the other hand, deselenylation of compound 11i with 
triphenyltin hydride furnished a mixture of the epimeric oxazepines 17i and epi-17i in 70:30 ratio. Interestingly, the stereoselection reaction was reversed when tributyltin hydride was used instead of triphenyltin hydride, and oxazepine epi-17i was obtained as major product, although with a low diastereoselectivity.
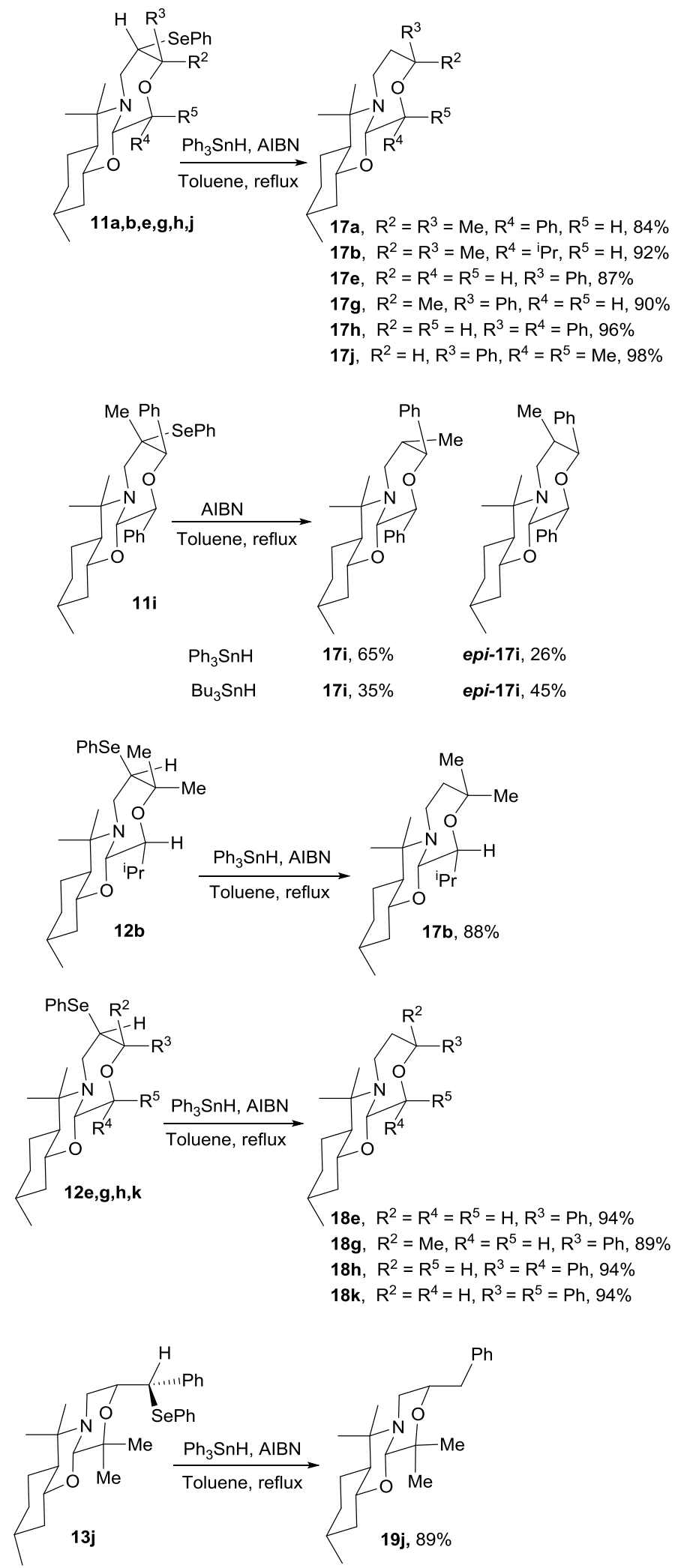

Scheme 3. Deselenylation of compounds 11a,b,e,g,h,l,j, 12b,e,g,h,k and 13j. 
The structure and stereochemistry of $11 \mathbf{h}, 12 \mathbf{b}, 12 \mathbf{h}, 19 \mathbf{j}, 11 \mathbf{k}, 12 \mathbf{k}$ and $18 \mathrm{e}$ was determined from COSY and NOESY experiments, whereas the structure, including the absolute configuration of compounds $\mathbf{1 4 b}, \mathbf{1 2 f}$ and $\mathbf{1 5 f}$ was established by X-ray diffraction studies.

On the other hand, the absolute configuration of the newly created stereocenters in $\mathbf{1 1} \mathbf{j}$ was determined by its conversion into the aminomenthol derivatives $\mathbf{2 0}$ by nucleophilic ring opening of the N,O-acetal moiety by aluminum hydride (Scheme 4) and X-ray diffraction analysis. In the same way, transformation of $\mathbf{1 8 g}$ into $\mathbf{2 1}$ (scheme 4) and X-ray diffraction analysis allowed the assignation of the absolute stereochemistry of $\mathbf{1 2 g}$, assuming an antiaddition in the selenociclization step on the basis of the literature precedents.
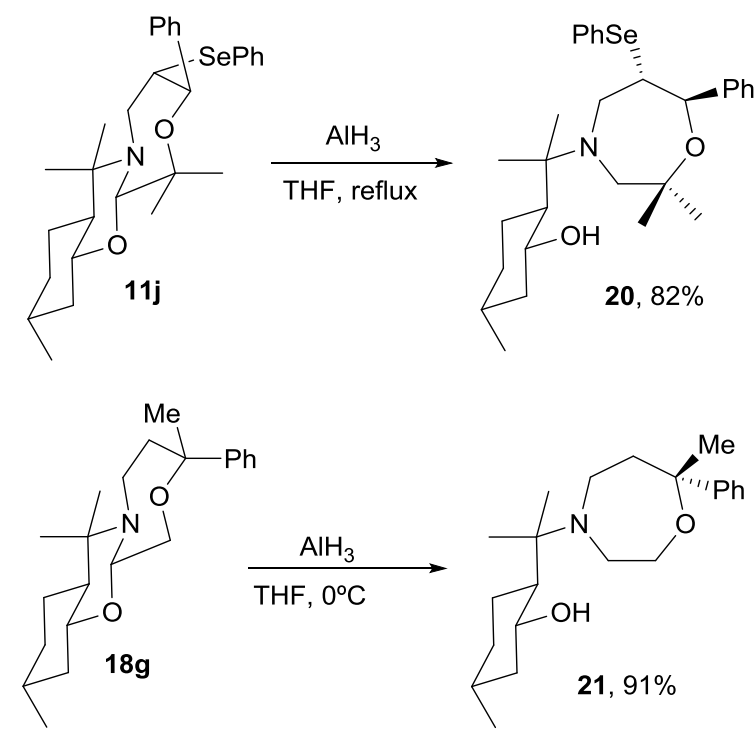

Scheme 4. Stereochemical Correlation of Compound 11j and 18g.

The utility of these selenocyclofunctionalization reactions was demonstrated by transformation of some deselenenylation products into the final chiral, nonracemic 1,4oxazepanes, which was achieved with moderate chemical yield as depicted in Scheme 5. The reductive ring opening of the $N, O$-ketal moiety in $\mathbf{1 7 a}, \mathbf{e}, \mathbf{h}, \mathbf{i}, \mathbf{j}$ and $18 \mathbf{e}, \mathbf{g}, \mathbf{k}$ by aluminum hydride, generated in situ from lithium aluminum hydride and aluminum chloride, in THF led to the amino menthol derivatives in good to excellent yields. The elimination of the menthol appendage in these derivatives was effected by oxidation with $\mathrm{PCC}$ in $\mathrm{CH}_{2} \mathrm{Cl}_{2}$ at room temperature to the corresponding 8 -aminomenthone derivatives followed by $\beta$-elimination by treatment with $\mathrm{KOH}$ in $\mathrm{H}_{2} \mathrm{O}-\mathrm{THF}-\mathrm{MeOH}$. The resulting 1,4-oxazepanes were characterized as N-tosyl derivatives $\mathbf{2 2 a}, \mathbf{e}, \mathbf{h}, \mathbf{i}, \mathbf{j}$ and $\mathbf{2 3 e , g , \mathbf { k }}$ by treatment with tosyl chloride and diisopropylethylamine in ethyl acetate. The absolute stereochemistry of compound $\mathbf{2 2 \mathbf { i }}$ was established by X-ray diffraction analysis corroborating the absolute configuration of $\mathbf{1 1 i}$ and that no racemization occurred during the elimination of the chiral auxiliary.

The described 7-endo-selenocyclization reactions using chiral 3-prenyl and 3-cinnamyl2-hydroxymethylperhydro-1,3-benzoxazine derivatives as starting products provides a novel and stereoselective synthesis of enantiopure 1,4-oxazepanes. Both enantiomers can be obtained simply starting from epimeric alcohols or modifying the reaction conditions. Obviously this 
method of synthesis of 1,4-oxazepanes is limited by the type of substituents at the double bond. With the purpose of increasing the scope of this selenocyclization reaction we have examined the possibility to obtain 1,4-oxazepanes by 7-exo-selenocyclization reaction starting from 3homoallylperhydrobenzoxazine derivatives.

The alcohol 26 was prepared by condensation of the (-)-8-homoallylaminomenthol $\mathbf{2 4}^{34}$ with phenylgyoxal in toluene at reflux followed by reduction of the carbonyl group in the resulting 2-benzoilbenzoxazine 25 with sodium borohydride in ethanol at $-10{ }^{\circ} \mathrm{C}$. This reduction turns out with a diastereomeric excess of 93\%, and alcohol 26 was obtained as a single diastereomer after recrystallization twice. Selenocyclization of alcohol 26 was carried out in $\mathrm{CH}_{2} \mathrm{Cl}_{2}$ at $-15{ }^{\circ} \mathrm{C}$ in presence of $\mathrm{PhSeCl}$ and $\mathrm{SnCl}_{4}$ and a mixture of two diastereoisomeric 1,4oxazepanes 27 and 28 in a 80/20 ratio was formed with a good chemical yield (72\%) (Scheme 6). COSY and NOESY experiments for the major diastereoisomer 27 allowed the establishment of their stereochemistry.
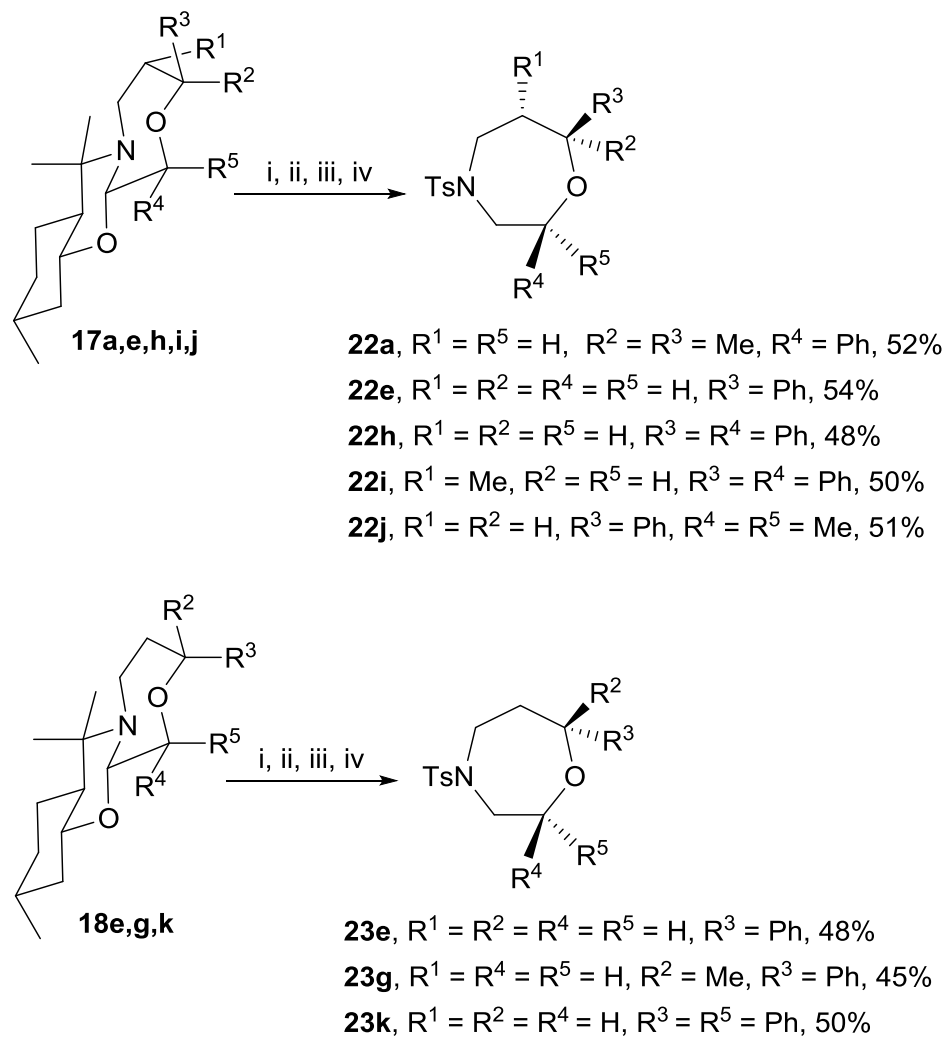

Scheme 5. Transformation of $\mathbf{1 7} \mathbf{a}, \mathbf{e}, \mathbf{h}, \mathbf{i}, \mathbf{j}$ and $\mathbf{1 8 e}, \mathbf{g}, \mathbf{k}$ into 1,4-oxazepanes $\mathbf{2 2 a}, \mathbf{e}, \mathbf{h}, \mathbf{I}, \mathbf{j}$ and 23e,g,k. Reagents and conditions: (i) $\mathrm{LiAlH}_{4}, \mathrm{AlCl}_{3}$, THF, $0^{\circ} \mathrm{C}$. (ii) $\mathrm{PCC}, \mathrm{CH}_{2} \mathrm{Cl}_{2}, 3 \AA$ molecular sieves, rt. (iii) Aqueous solution of $\mathrm{KOH} 2.5 \mathrm{M} \mathrm{MeOH}$, THF, rt. (iv) TsCl, DIPEA, ethyl acetate, rt. 

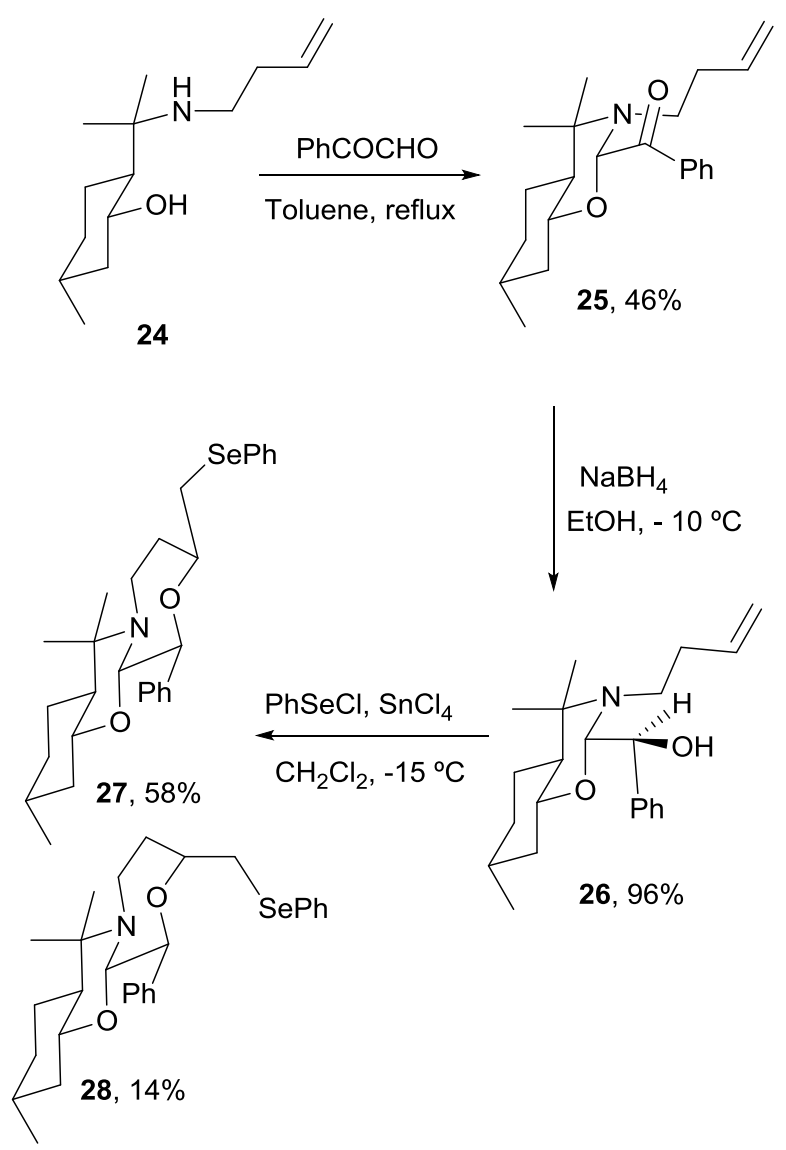

Scheme 6. Synthesis and Selenocyclofunctionalization of Alcohol 26.

\section{Conclusions}

In summary, the synthetic sequence described above constitutes a short and efficient procedure for the preparation of a variety of enantiopure 1,4-oxazepanes with up to three stereocenters. The regio and stereochemistry of the cyclization products was dependent of the substitution pattern of the double bond, the nature of the hydroxyl group and the experimental conditions. The best regio and diastereoselectivities were achieved in selenocyclofunctionalization of $\mathrm{N}$-cinnamylperhydro-1,3-benzoxazines bearing a secondary or tertiary hydroxyl group with $\mathrm{PhSeCl}$ in $\mathrm{CH}_{2} \mathrm{Cl}_{2}$ in the presence of $\mathrm{SnCl}_{4}$ at $-78{ }^{\circ} \mathrm{C}$.

\section{Experimental section}

\section{General experimental procedures}

All reactions were carried out in anhydrous solvents, under argon atmosphere, and in oven-dried glassware. Commercial reagents were used without purification. ${ }^{1} \mathrm{H}$ NMR (300 $\mathrm{MHz}$ ) and ${ }^{13} \mathrm{C}$ NMR (75 MHz) spectra were recorded in $\mathrm{CDCl}_{3}$. Chemical shifts for protons are reported in ppm from tetramethylsilane with the residual $\mathrm{CHCl}_{3}$ resonance as an internal reference. Chemical shifts for carbons are reported in ppm from tetramethylsilane and are referenced to the carbon resonance of the solvent. Data are reported as follows: chemical shift, multiplicity $(\mathrm{s}=$ singlet, $\mathrm{d}=$ doublet, $\mathrm{t}=$ triplet, $\mathrm{q}=$ quartet, $\mathrm{sp}=$ septet, $\mathrm{m}=$ multiplet, $\mathrm{br}=$ 
broad), coupling constants in hertz, and integration. High resolution mass spectrometry analysis (HRMS) was performed by a quadrupole spectrometer with a TOF analyzer. Specific rotations were measured using a $5 \mathrm{~mL}$ cell with a $1 \mathrm{dm}$ path length, and a sodium lamp, and concentration is given in g per $100 \mathrm{~mL}$. Melting points were determined in open capillary tubes and are uncorrected. Flash chromatography was carried out using silica gel (230-240 mesh). TLC analysis was performed on glass-backed plates coated with silica gel 60 and an F254 indicator, and visualized by either UV irradiation or by staining with $\mathrm{I}_{2}$ or phosphomolybdic acid solution. Chemical yields refer to pure isolated substances. described. ${ }^{21}$

Compounds 11a, 11d, 12d, 13c, 13d, 14a, 14c and 17a have been previously

Compounds 11e, 11f, 12a, 12e, 13a, 13b, 14d, 15i and 16i could not be isolated and obtained pure after flash chromatography.

\section{General procedure for selenocyclization reactions.}

Method A. To a stirred solution of $\mathrm{PhSeCl}(0.92 \mathrm{~g}, 4.8 \mathrm{mmol})$ in anhydrous $\mathrm{CH}_{2} \mathrm{Cl}_{2}$ (30 $\mathrm{mL}$ ) cooled to $-78{ }^{\circ} \mathrm{C}$, a solution of $\mathrm{SnCl}_{4}$ in $\mathrm{CH}_{2} \mathrm{Cl}_{2}(5.0 \mathrm{~mL}$ of $1.0 \mathrm{M}$ solution, Aldrich) was added dropwise under nitrogen atmosphere. The mixture was stirred for $15 \mathrm{~min}$, and then it was added dropwise to a solution of the appropriate alcohol 10a-k $(4.0 \mathrm{mmol})$ in $\mathrm{CH}_{2} \mathrm{Cl}_{2}(15 \mathrm{~mL})$ cooled to $-78{ }^{\circ} \mathrm{C}$. Stirring was continued for $2.5 \mathrm{~h}$ at $-78{ }^{\circ} \mathrm{C}$ (and additional $4 \mathrm{~h}$ at $-22{ }^{\circ} \mathrm{C}$ for alcohol 10f and 10i) and then the mixture was treated with a $10 \%$ aqueous solution of $\mathrm{NaOH}$ $(40 \mathrm{~mL})$. The layers were separated and the aqueous was extracted with $\mathrm{CH}_{2} \mathrm{Cl}_{2}(3 \times 20 \mathrm{~mL})$. The combined organic layers were washed with brine, dried over $\mathrm{MgSO}_{4}$, concentrated at reduced pressure, and the residue was purified by flash chromatography on silica gel, using hexanes-ethyl acetate as eluent.

Selenocyclization of alcohol 26 was carried out starting from $0.45 \mathrm{~g}$ of $\mathbf{2 6}$ with $\mathrm{PhSeCl}$ in $\mathrm{CH}_{2} \mathrm{Cl}_{2}$ in the presence of $\mathrm{SnCl}_{4}$ at $-15{ }^{\circ} \mathrm{C}$ for 7 hours.

Method B. To a stirred solution of the appropriate alcohol 10a-k $(4.0 \mathrm{mmol})$ in acetonitrile $(30 \mathrm{~mL})$ was added, in portions, $\mathrm{PhSeCl}(1.07 \mathrm{~g}, 5.6 \mathrm{mmol})$. The stirring was continued for $14 \mathrm{~h}$ at room temperature and then treated with a $10 \%$ aqueous solution of $\mathrm{NaOH}$ $(40 \mathrm{~mL})$. The acetonitrile was evaporated in vacuo and the remained aqueous phase was extracted with $\mathrm{CH}_{2} \mathrm{Cl}_{2}(3 \times 20 \mathrm{~mL})$ and the products isolated as described for method A.

\section{General procedure for reductive deselenylation.}

A mixture of AIBN (33 mg, $0.2 \mathrm{mmol})$, triphenyltin hydride $(0.91 \mathrm{~g}, 2.6 \mathrm{mmol})$ and the appropriated selenenylated compound $(1.7 \mathrm{mmol})$ in degassed toluene $(30 \mathrm{~mL})$ was heated at reflux under argon atmosphere until disappearance of the starting product (TLC, 30-120 min.). The solvent was removed in vacuo and the residue was chromatographed on silica gel using hexanes/AcOEt as eluent. 


\section{General method for elimination of the chiral auxiliary.}

To a suspension of $\mathrm{LiAlH}_{4}(0.70 \mathrm{~g}, 18.8 \mathrm{mmol})$ in anhydrous THF $(30 \mathrm{~mL})$ cooled to $10^{\circ} \mathrm{C}$ and under nitrogen atmosphere was added, in portions, dry $\mathrm{AlCl}_{3}(0.85 \mathrm{~g}, 6,3 \mathrm{mmol})$. The mixture was stirred for $15 \mathrm{~min}$ at $-10^{\circ} \mathrm{C}$ and a solution of the corresponding benzoxazine $\mathbf{1 7} \mathbf{a}, \mathbf{e}, \mathbf{h}, \mathbf{i}, \mathbf{j}$ or $\mathbf{1 8 e}, \mathbf{g}, \mathbf{k}(2.5 \mathrm{mmol})$ in dry THF $(20 \mathrm{~mL})$ was slowly added. The reaction mixture was stirred at $0{ }^{\circ} \mathrm{C}$ until disappearance of the starting product (TLC) and then it was quenched by addition of $10 \%$ aqueous solution of $\mathrm{NaOH}(1.5 \mathrm{~mL})$. The resulting mixture was filtered, the solid was washed with hot EtOAc, and the organic layer was dried over anhydrous $\mathrm{MgSO}_{4}$. The solvent was eliminated under reduced pressure, the residue was redissolved in anhydrous $\mathrm{CH}_{2} \mathrm{Cl}_{2}(35 \mathrm{~mL})$, and PCC (2.2 g, $\left.10.0 \mathrm{mmol}\right)$ and $3 \AA$ molecular sieves $(4.0 \mathrm{~g})$ was added to this solution. The mixture was stirred under nitrogen atmosphere until the oxidation was finished (TLC 3-6 h). The mixture was then treated with a $10 \%$ aqueous solution of $\mathrm{NaOH}(60$ $\mathrm{mL})$ and extracted with $\mathrm{CHCl}_{3}(5 \times 25 \mathrm{~mL})$. The organic phase was washed with brine, dried over anhydrous $\mathrm{MgSO}_{4}$ and the solvent were removed under reduced pressure. The residue was redisolved in THF $(30 \mathrm{~mL})$ and $\mathrm{MeOH}(15 \mathrm{ml})$, an aqueous solution of $\mathrm{KOH} 2.5 \mathrm{M}(15 \mathrm{~mL})$ was added and the mixture stirred at room temperature for $4.5 \mathrm{~h}$. After elimination of the THF and $\mathrm{MeOH}$ under reduced pressure, the residue was acidified with a $1 \mathrm{M}$ solution of $\mathrm{HCl}$ to $\mathrm{pH} 2$ and extracted twice with $\mathrm{Et}_{2} \mathrm{O}(2 \times 20 \mathrm{~mL})$. The aqueous solution was neutralized to $\mathrm{pH} 12$ with a $10 \%$ aqueous solution of $\mathrm{NaOH}$ and extracted with $\mathrm{CHCl}_{3}(4 \times 20 \mathrm{~mL})$. The organic layer was washed with $\mathrm{H}_{2} \mathrm{O}$, dried over $\mathrm{MgSO}$, and the solvent eliminated under vacuum. The morpholines obtained in this way was characterized as $\mathrm{N}$-tosyl derivatives that were obtained pure by treatment with an excess of tosyl chloride and diisopropylethylamine in ethyl acetate for $50 \mathrm{~h}$, elimination of the solvent under vacuum and cromatography on silica gel using hexanes/EtOAc 20:1 as eluent.

(2S)-7,7-Dimethyl-2-phenyl-4-tosyl-1,4-oxazepane (22a). This compound was obtained from 17a $(0.9 \mathrm{~g})$. Yield: $0.47 \mathrm{~g} \mathrm{52 \%}$. Colorless solid. Mp: $125-126^{\circ} \mathrm{C}$ (from hexane). [ $\alpha]_{\mathrm{D}}{ }^{25}=+104.9\left(\mathrm{c}=4.2, \mathrm{CH}_{2} \mathrm{Cl}_{2}\right) .{ }^{1} \mathrm{H} \operatorname{NMR}(\delta): 1.18(\mathrm{~s}, 3 \mathrm{H}) ; 1.19(\mathrm{~s}, 3 \mathrm{H}) ; 1.95\left(\mathrm{dd}, 1 \mathrm{H}, J_{1}=\right.$ $\left.15.5 \mathrm{~Hz}, J_{2}=7.4 \mathrm{~Hz}\right) ; 2.12\left(\mathrm{dd}, 1 \mathrm{H}, J_{1}=15.5 \mathrm{~Hz}, J_{2}=9.1 \mathrm{~Hz}\right) ; 2.39(\mathrm{~s}, 3 \mathrm{H}) ; 3.65\left(\mathrm{dd}, 1 \mathrm{H}, J_{1}\right.$ $\left.=12.8 \mathrm{~Hz}, J_{2}=9.1 \mathrm{~Hz}\right) ; 2.82\left(\mathrm{dd}, 1 \mathrm{H}, J_{1}=13.4 \mathrm{~Hz}, J_{2}=9.1 \mathrm{~Hz}\right) ; 3.87\left(\mathrm{dd}, 1 \mathrm{H}, J_{1}=13.4 \mathrm{~Hz}, J_{2}=\right.$ $7.5 \mathrm{~Hz}) ; 3.97(\mathrm{~d}, 1 \mathrm{H}, J=12.8 \mathrm{~Hz}) ; 4.83(\mathrm{~d}, 1 \mathrm{H}, J=9.1 \mathrm{~Hz}) ; 7.20-7.38(\mathrm{~m}, 7 \mathrm{H}) ; 7.62(\mathrm{~d}, 2 \mathrm{H}, J=$ $8.3 \mathrm{~Hz}) .{ }^{13} \mathrm{C}$ NMR $(\delta): 21.3\left(\mathrm{CH}_{3}\right) ; 26.1\left(\mathrm{CH}_{3}\right) ; 29.1\left(\mathrm{CH}_{3}\right) ; 41.8\left(\mathrm{CH}_{2}\right) ; 43.6\left(\mathrm{CH}_{2}\right) ; 56.7\left(\mathrm{CH}_{2}\right)$; $73.4(\mathrm{CH}) ; 74.8(\mathrm{C}) ; 125.8(2 \mathrm{CH}) ; 127.0(2 \mathrm{CH}) ; 127.4(\mathrm{CH}) ; 128.1(2 \mathrm{CH}) ; 129.5(2 \mathrm{CH})$; 135.0 (C); 140.6 (C); 143.1 (C). IR (Nujol dispersion): 3.065, 3030, 1600, 1495, 765, 725, 700, $660,620 \mathrm{~cm}^{-1}$. HRMS calcd for $\mathrm{C}_{20} \mathrm{H}_{25} \mathrm{NO}_{3} \mathrm{NaS}[\mathrm{M}+\mathrm{Na}]^{+} 382.1447$, found 382.1441 .

(7S)-7-Phenyl-4-tosyl-1,4-oxazepane (22e). This compound was obtained from 17e $(0.4 \mathrm{~g})$. Yield: $0.22 \mathrm{~g}, 54 \%$. Colorless solid. Mp: $120-121^{\circ} \mathrm{C}$ (from hexane). $[\alpha]_{\mathrm{D}}{ }^{25}=+37.6(\mathrm{c}=$ 0.5, $\left.\mathrm{CH}_{2} \mathrm{Cl}_{2}\right) .{ }^{1} \mathrm{H}$ NMR $(\delta): 2.05(\mathrm{~m}, 1 \mathrm{H}) ; 2.33(\mathrm{~m}, 1 \mathrm{H}) ; 2.46(\mathrm{~s}, 3 \mathrm{H}) ; 3.23(\mathrm{~m}, 1 \mathrm{H}) ; 3.33$ (ddd, $\left.1 \mathrm{H}, J_{1}=13.0 \mathrm{~Hz}, J_{2}=7.8 \mathrm{~Hz}, J_{3}=4.5 \mathrm{~Hz}\right) ; 3.57-3.82(\mathrm{~m}, 3 \mathrm{H}) ; 4.11\left(\mathrm{dt}, 1 \mathrm{H}, J_{1}=13.0 \mathrm{~Hz}, J_{2}=\right.$ $3.3 \mathrm{~Hz}) ; 4.68\left(\mathrm{dd}, 1 \mathrm{H}, J_{1}=9.6 \mathrm{~Hz}, J_{2}=4.2 \mathrm{~Hz}\right) ; 7.24-7.39(\mathrm{~m}, 7 \mathrm{H}) ; 7.72(\mathrm{~d}, 2 \mathrm{H}, J=8.2 \mathrm{~Hz}) .{ }^{13} \mathrm{C}$

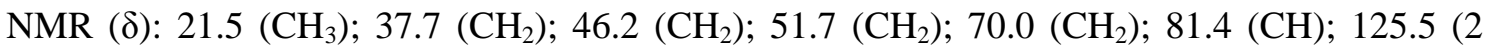
$\mathrm{CH}) ; 127.0(2 \mathrm{CH}) ; 127.4(\mathrm{CH}) ; 128.4(2 \mathrm{CH}) ; 129.7(2 \mathrm{CH}) ; 135.9(\mathrm{C}) ; 142.8(\mathrm{C}) ; 143.4(\mathrm{C})$. IR (Nujol dispersion): 3040, 1595, 770, 720, 700, $690 \mathrm{~cm}^{-1}$. HRMS calcd for $\mathrm{C}_{18} \mathrm{H}_{21} \mathrm{NO}_{3} \mathrm{NaS}[\mathrm{M}$ $+\mathrm{Na}]^{+} 354.1134$, found 354.1139 .

(2S,7S)-2,7-Diphenyl-4-tosyl-1,4-oxazepane (22h). This compound was obtained from 17h $\left(0.50\right.$ g). Yield: $0.24 \mathrm{~g}, 48 \%$. Colorless oil. $[\alpha]_{\mathrm{D}}{ }^{25}=+18.0\left(\mathrm{c}=0.7 \mathrm{CH}_{2} \mathrm{Cl}_{2}\right) .{ }^{1} \mathrm{H} \mathrm{NMR}(\delta)$ : 
$2.08(\mathrm{~m}, 1 \mathrm{H}) ; 2.41(\mathrm{~s}, 3 \mathrm{H}) ; 2.52(\mathrm{~m}, 1 \mathrm{H}) ; 2.91\left(\mathrm{dd}, 1 \mathrm{H}, J_{1}=13.7 \mathrm{~Hz}, J_{2}=10.2 \mathrm{~Hz}\right) ; 3.15$ (ddd, $\left.1 \mathrm{H}, J_{1}=14.2 \mathrm{~Hz}, J_{2}=8.8 \mathrm{~Hz}, J_{3}=5.6 \mathrm{~Hz}\right) ; 3.91(\mathrm{~m}, 1 \mathrm{H}) ; 4.09\left(\mathrm{dd}, 1 \mathrm{H}, J_{1}=13.7 \mathrm{~Hz}, J_{2}=2.6\right.$ $\mathrm{Hz}) ; 4.85\left(\mathrm{dd}, 1 \mathrm{H}, J_{1}=10.2 \mathrm{~Hz}, J_{2}=2.6 \mathrm{~Hz}\right) ; 5.00\left(\mathrm{dd}, 1 \mathrm{H}, J_{1}=9.7 \mathrm{~Hz}, J_{2}=4.7 \mathrm{~Hz}\right) ; 7.21-7.40$ $(\mathrm{m}, 12 \mathrm{H}) ; 7.68(\mathrm{~d}, 2 \mathrm{H}, J=8.2 \mathrm{~Hz}) .{ }^{13} \mathrm{C}$ NMR $(\delta): 21.5\left(\mathrm{CH}_{3}\right) ; 38.6\left(\mathrm{CH}_{2}\right) ; 46.6,\left(\mathrm{CH}_{2}\right) ; 58.7$ $\left(\mathrm{CH}_{2}\right) ; 80.6(\mathrm{CH}) ; 83.5(\mathrm{CH}) ; 125.3(2 \mathrm{CH}) ; 125.9(2 \mathrm{CH}) ; 126.9(2 \mathrm{CH}) ; 127.1(\mathrm{CH}) ; 127.7$ $(\mathrm{CH}) ; 128.2(2 \mathrm{CH}) ; 128.3(2 \mathrm{CH}) ; 129.8(2 \mathrm{CH}) ; 136.2$ (C); $139.6(\mathrm{C}) ; 143.4$ (2 C). IR (Film): 3060, 3020, 1595, 755, 740, 695, $655 \mathrm{~cm}^{-1}$. HRMS calcd for $\mathrm{C}_{24} \mathrm{H}_{25} \mathrm{NO}_{3} \mathrm{NaS}[\mathrm{M}+\mathrm{Na}]^{+}$ 430.1447 , found 430.1438 .

(2S,6S,7S)-2,7-Diphenyl-6-methyl-4-tosyl-1,4-oxazepane (22i). This compound was obtained from 17i $(0.35 \mathrm{~g})$. Yield: $0.18 \mathrm{~g}, 50 \%$. Colorless solid. Mp: $156-147{ }^{\circ} \mathrm{C}$ (from hexaneEtOAc). $[\alpha]_{\mathrm{D}}{ }^{25}=+14.9\left(\mathrm{c}=1.0 \mathrm{CH}_{2} \mathrm{Cl}_{2}\right) .{ }^{1} \mathrm{H} \mathrm{NMR}(\delta): 1.07(\mathrm{~d}, 3 \mathrm{H}, J=6.9 \mathrm{~Hz}) ; 2.27(\mathrm{~m}, 1 \mathrm{H})$; $2.40(\mathrm{~s}, 3 \mathrm{H}) ; 2.76\left(\mathrm{dd}, 1 \mathrm{H}, J_{1}=12.9 \mathrm{~Hz}, J_{2}=10.7 \mathrm{~Hz}\right) ; 3.32\left(\mathrm{dd}, 1 \mathrm{H}, J_{1}=14.0 \mathrm{~Hz}, J_{2}=4.9 \mathrm{~Hz}\right)$; $3.62(\mathrm{~d}, 1 \mathrm{H}, J=14.0 \mathrm{~Hz}) ; 4.01\left(\mathrm{dd}, 1 \mathrm{H}, J=12.9 \mathrm{~Hz}, J_{2}=3.3 \mathrm{~Hz}\right) ; 4.38(\mathrm{~d}, 1 \mathrm{H}, J=9.4 \mathrm{~Hz}) ; 4.86$ $\left(\mathrm{dd}, 1 \mathrm{H}, J_{1}=10.7 \mathrm{~Hz}, J_{2}=3.9 \mathrm{~Hz}\right) ; 7.19-7.35(\mathrm{~m}, 12 \mathrm{H}) ; 7.67(\mathrm{~d}, 2 \mathrm{H}, J=8.3 \mathrm{~Hz}) .{ }^{13} \mathrm{C} \mathrm{NMR}(\delta)$ : $16.7\left(\mathrm{CH}_{3}\right) ; 21.4\left(\mathrm{CH}_{3}\right) ; 42.5(\mathrm{CH}) ; 54.1\left(\mathrm{CH}_{2}\right) ; 59.0\left(\mathrm{CH}_{2}\right) ; 84.1(\mathrm{CH}) ; 88.9(\mathrm{CH}) ; 125.8(2$ $\mathrm{CH}) ; 126.7(2 \mathrm{CH}) ; 127.1(2 \mathrm{CH}) ; 127.4(\mathrm{CH}) ; 127.6(\mathrm{CH}) ; 128.1(2 \mathrm{CH}) ; 128.2(2 \mathrm{CH}) ; 129.7$ (2 CH); 135.5 (C); 139.7 (C); 122.4 (C); 143.3 (C). IR (Nujol dispersion): 3050, 3025, 1600, 1495, 760, 750, 695, $665 \mathrm{~cm}^{-1}$. HRMS calcd for $\mathrm{C}_{25} \mathrm{H}_{27} \mathrm{NO}_{3} \mathrm{NaS}[\mathrm{M}+\mathrm{Na}]^{+} 444.1604$, found 444.159.

(7S)-2,2-Dimethyl-7-phenyl-4-tosyl-1,4-oxazepane (22j). This compound was obtained from 17j $(0.75 \mathrm{~g})$. Yield: $0,38 \mathrm{~g}, 51 \%$. Colorless solid. Mp: $114-115{ }^{\circ} \mathrm{C}$ (from hexaneEtOAc). $[\alpha]_{\mathrm{D}}{ }^{25}=-21.6\left(\mathrm{c}=2.7, \mathrm{CH}_{2} \mathrm{Cl}_{2}\right) .{ }^{1} \mathrm{H}$ NMR $(\delta): 1.26(\mathrm{~s}, 3 \mathrm{H}) ; 1.36(\mathrm{~s}, 3 \mathrm{H}) ; 2.02-2.11(\mathrm{~m}$, $2 \mathrm{H}) ; 2.41(\mathrm{~s}, 3 \mathrm{H}) ; 2.98\left(\mathrm{ddd}, 1 \mathrm{H}, J_{1}=12.6 \mathrm{~Hz}, J_{2}=9.2 \mathrm{~Hz}, J_{3}=7.0 \mathrm{~Hz}\right) ; 3.07(\mathrm{~d}, 1 \mathrm{H}, J=14.4$ $\mathrm{Hz}) ; 3.38(\mathrm{~d}, 1 \mathrm{H}, J=14.4 \mathrm{~Hz}) ; 3.52\left(\mathrm{td}, 1 \mathrm{H}, J_{1}=12.6 \mathrm{~Hz}, J_{2}=4.6 \mathrm{~Hz}\right) ; 4.70\left(\mathrm{dd}, 1 \mathrm{H}, J_{1}=8.0\right.$ $\left.\mathrm{Hz}, J_{2}=3.8 \mathrm{~Hz}\right) ; 7.18-7.33(\mathrm{~m}, 7 \mathrm{H}) ; 7.68(\mathrm{~d}, 2 \mathrm{H}, J=8.3 \mathrm{~Hz}) .{ }^{13} \mathrm{C} \mathrm{NMR}(\delta): 21.4\left(\mathrm{CH}_{3}\right) ; 23.3$ $\left(\mathrm{CH}_{3}\right) ; 27.7\left(\mathrm{CH}_{2}\right) ; 38.4\left(\mathrm{CH}_{2}\right) ; 49.1\left(\mathrm{CH}_{2}\right) ; 58.8\left(\mathrm{CH}_{2}\right) ; 72.3(\mathrm{CH}) ; 74.6(\mathrm{C}) ; 125.6(2 \mathrm{CH})$; $127.0(\mathrm{CH}) ; 127.1(2 \mathrm{CH}) ; 128.1(2 \mathrm{CH}) ; 129.6(2 \mathrm{CH}) ; 135.2(\mathrm{C}) ; 143.3(\mathrm{C}) ; 143.6(\mathrm{C}) . \mathrm{IR}$ (Nujol dispersion): 3060, 3030, 1600, 1495, 780, 745, 700, $655 \mathrm{~cm}^{-1}$. HRMS calcd for $\mathrm{C}_{20} \mathrm{H}_{25} \mathrm{NO}_{3} \mathrm{NaS}[\mathrm{M}+\mathrm{Na}]^{+}$382.1447, found 382.1462.

(7R)-7-Phenyl-4-tosyl-1,4-oxazepane (23e). This compound was obtained from 18e $(0.80 \mathrm{~g})$. Yield: $0.39 \mathrm{~g}, 48 \%$. Colorless solid. Mp: $119-120^{\circ} \mathrm{C}$ (from hexane). $[\alpha]_{\mathrm{D}}{ }^{25}=-33.3(\mathrm{c}=$ $0.5, \mathrm{CH}_{2} \mathrm{Cl}_{2}$ ). ${ }^{1} \mathrm{H}-\mathrm{NMR},{ }^{13} \mathrm{C}-\mathrm{NMR}$ and IR data are coincident with those reported for 22e. Anal. Calcd for $\mathrm{C}_{18} \mathrm{H}_{21} \mathrm{NO}_{3} \mathrm{NaS}[\mathrm{M}+\mathrm{Na}]^{+} 354.1134$, found 354.1134.

(7R)-7-Methyl-7-phenyl-4-tosyl-1,4-oxazepane (23g). This compound was obtained from $18 \mathrm{~g}(0.75 \mathrm{~g})$. Yield: $0.34 \mathrm{~g}, 45 \%$. Colorless solid. Mp: $124-125{ }^{\circ} \mathrm{C}$ (from hexane). $[\alpha]_{\mathrm{D}}{ }^{25}=$ -19.0 (c = 0.6 $\left.\mathrm{CH}_{2} \mathrm{Cl}_{2}\right) .{ }^{1} \mathrm{H}$ NMR $(\delta): 1.33(\mathrm{~s}, 3 \mathrm{H}) ; 2.40-2.51(\mathrm{~m}, 2 \mathrm{H}) ; 2.42(\mathrm{~s}, 3 \mathrm{H}) ; 3.02-3.12$ $(\mathrm{m}, 2 \mathrm{H}) ; 3.48-3.67(\mathrm{~m}, 3 \mathrm{H}) ; 3.84\left(\mathrm{ddd}, 1 \mathrm{H}, J_{1}=13.6 \mathrm{~Hz}, J_{2}=4.6 \mathrm{~Hz}, J_{3}=1.9 \mathrm{~Hz}\right) ; 7.26(\mathrm{~m}$, $1 \mathrm{H}) ; 7.29-7.35(\mathrm{~m}, 6 \mathrm{H}) ; 7.64(\mathrm{~d}, 2 \mathrm{H}, J=8.3 \mathrm{~Hz}) .{ }^{13} \mathrm{C} \mathrm{NMR}(\delta): 21.5\left(\mathrm{CH}_{3}\right) ; 30.9\left(\mathrm{CH}_{3}\right) ; 41.1$ $\left(\mathrm{CH}_{2}\right) ; 43.5\left(\mathrm{CH}_{2}\right) ; 50.8\left(\mathrm{CH}_{2}\right) ; 63.9\left(\mathrm{CH}_{2}\right) ; 79.5(\mathrm{C}) ; 125.0(2 \mathrm{CH}) ; 126.8(\mathrm{CH}) ; 127.2(2 \mathrm{CH})$; 128.3 (2 CH); 129.7 (2 CH); 134.7 (C); 143.4 (C); 147.2 (C). IR (Nujol dispersion): 3085, 3045, $3025,1595,1490,765,720,700,650 \mathrm{~cm}^{-1}$. HRMS calcd for $\mathrm{C}_{19} \mathrm{H}_{23} \mathrm{NO}_{3} \mathrm{NaS}[\mathrm{M}+\mathrm{Na}]^{+}$ 368.1291 , found 368.1297 .

(2R,7R)-2,7-Diphenyl-4-tosyl-1,4-oxazepane (23k). This compound was obtained from 18k $(0.55 \mathrm{~g})$. Yield: $0.28 \mathrm{~g}, 50 \%$. Colorless oil. $[\alpha]_{\mathrm{D}}{ }^{25}=-20.4\left(\mathrm{c}=0.9 \mathrm{CH}_{2} \mathrm{Cl}_{2}\right) .{ }^{1} \mathrm{H}-\mathrm{NMR}$, 
${ }^{13} \mathrm{C}$-NMR and IR data are coincident with those reported for $\mathbf{2 2 h}$. HRMS calcd for $\mathrm{C}_{24} \mathrm{H}_{25} \mathrm{NO}_{3} \mathrm{NaS}[\mathrm{M}+\mathrm{Na}]^{+}$430.1447, found 430.1443.

\section{Acknowledgements}

Authors thank the Spanish DGICYT (Project CTQ2014-59870-P) and JCyL (Project VA064U13) for financial support. We also thank Dr. José M. Martín-Álvarez for his assistance in the determination of the $\mathrm{X}$-ray structures.

\section{Notes and references}

1 For a review on 1,4-oxazepines see: I. Ninomiya, T. Naito and O. Miyata, in Comprehensive Heterocyclic Chemistry II, ed. A. R. Katritzky, C. W. Rees, E. F. V. Scriven, Pergamon, Oxford, 1996, vol. 9, ch. 9, pp. 217-231.

2 (a) S. Kaneko, M. Arai, T. Uchida, T. Harasaki, T. Fukuoka and T. Konosu, . Bioorg. Med. Chem. Lett., 2002, 12, 1705. (b) M. H. Serrano-Wu, D. R. St. Laurent, Y. Chen, S. Huang, K-R. Lam, J. A. Matson, C. E. Mazzucco, T. M. Stickle, T. P. Tully, H. S. Wong, D. M. Vyas and B. N. Balasubramanian, Bioorg. Med. Chem. Lett., 2002, 12, 2757.

3 (a) A. D. Cale Jr., T. W. Gero, K. R. Walter, Y. S. Lo, W. J. Welstead Jr., L. W. Jaques, A. F. Johnson, C. A. Leonard, J. C. Nolan and D. N. Johnson, J. Med. Chem., 1989, 32, 2178. (b) R. A. Smits, H. D. Lim, B. Stegink, R. A. Bakker, I. J. P, de Esch and R. Leurs, R. J. Med. Chem., 2006, 49, 4512 .

4 (a) G. Sharma, J. Y. Park, M. S. Park, Bioorg. Med. Chem. Lett., 2008, 18, 3188 (b) Gitalee Sharma, Jin Yup Park, and Min Soo Park, Arch. Pharm. Res., 2008, 31, 838.

5 (a) E. A. Hallinan, A. Stapelfeld, M. A. Savage and M. Reichman,. Bioorg. Med. Chem. Lett., 1994, 4, 509. (b) E. A. Hallinan, T. J. Hagen, S. Tsymbalov, R. K. Husa, A. C. Lee, A. Stapelfeld and M. A. Savage, J. Med. Chem., 1996, 39, 609.

6 G. Campiani, V. Nacci, I. Fiorini, M. P. De Filippis, A. Garofalo, G. Greco, E. Novellino, S. Altamura and, L. Di Renzo, J. Med. Chem., 1996, 39, 2672.

7 J. A. Robl, L. M. Simpkins and M. M. Asaad, Bioorg. Med. Chem. Lett., 2000, 10, 257.

8 M. M. Mc Gee, S. Gemma, S. Butini, A. Ramunno, D. M. Zisterer, C. Fattorusso, B. Catalanotti, G. Kukreja, I. Fiorini, C. Pisano, C. Cucco, E. Novellino, V. Nacci, D. C. Williams and G. Campani,. Med. Chem., 2005, 48, 4367.

9 P. A. Burland, H. M. I. Osborn and A. Turkson, ,Bioorg. Med. Chem. Lett., 2011, 19, 5679.

10 (a) W. Pan, H. Liu, Y.-J. Xu, X. Chen, K. H. Kim, D. L. Milligan, J. Columbus, Y. R. Hadari, P. Kussie, W. C. Wong and M. Labelle, Bioorg. Med. Chem. Lett., 2005, 15, 5474. (b) L. Smith II, W. C. Wong, A. S. Kiselyov, S. Burdzovic-Wizemann, Y. Mao, Y. Xu, M. A. J. Duncton, K. Kim, E. L. Piatnitski, J. F. Doody, Y. Wang, R. L. Rosler, D. Milligan, J. 
Columbus, C. Balagtas, S. P. Lee, A. Konovalov and Y. R. Hadari, Bioorg. Med. Chem. Lett., 2006, 16, 5102.

11 K. Shankaran, K. L. Donnelly, K. S. Shah, C. G. Caldwell, P. Chen, W. K. Hagmann, M. MacCoss, J. L. Humes, S. G. Pacholok, T. M. Kelly, S. K. Grant and K. K.Wong, Bioorg. Med. Chem. Lett., 2004, 14, 5907.

12 K. Audouze, E. Ø. Nielsenand D. Peters, J. Med. Chem., 2004, 47, 3089.

13 (a)T. J. Grinsteiner and Y. Kishi, Tetrahedron Lett., 1994, 45, 8337. (b) M. Kurosu, L. R. Marcin, T. J. Grinsteiner, Y. Kishi, J. Am. Chem. Soc., 1998, 120, 6627.

14 (a) T. Mukaiyama, T. Takeda and M. Osaki, Chem. Lett., 1977, 1165. (b) T. Mukaiyama, T. Takeda and K. Fujimoto,. Bull. Chem. Soc. Jpn., 1978, 51, 3368. (c) L. F. Tietze, S. Brand and T. Pfeiffer, Angew. Chem. Int. Ed. Engl., 1985, 24, 784. (d) L. F. Tietze, S. Brand, T. Pfeiffer, J. Antel, K. Harms and G. M. Sheldrick, J. Am. Chem. Soc., 1987, 109, 921. (e) B. M. Trost, B. Yang and M. L. Miller, J. Am. Chem. Soc., 1989, 111, 6482. (f) T. F. Kno1pfel, D. Boyall and E. M. Carreira, Org. Lett., 2004, 6, 2281. (g) J. C. S. Woo, S. Cui, S. D. Walker and M. M. Faul, Tetrahedron, 2010, 66, 4730

15 For some recent examples of estereoselective synthesis of substituted 1,4-oxazepanes, see: (a) S. M. Clark and H. M. I. Osborn, Tetrahedron: Asymmetry, 2004, 15, 3643. (b) C. W. Becker,B. T. Dembofsky, J. E. Hall, R. T. Jacobs, D. E. Pivonka and C. J. Ohnmacht, Synthesis, 2005, 2549. (c) J. Nonnenmacher, F. Grellepois and Charles Portella, Eur. J. Org. Chem., 2009, 3726. (d) M. K. Ghorai, D. Shukla and K. Das, J. Org. Chem., 2009, 74, 7013. (e) K. Samanta and G. Panda, Org. Biomol. Chem. 2011, 9, 7365 ( $f$ ) R. Zhou, J. Wang, C. Duan and and Z. He, Org. Lett., 2012, 14, 6134. (h) M. Bezanson, J. Pottel, R. Bilbeisi, S. Toumieux, M. Cueto and N. Moitessier, J. Org. Chem., 2013, 78, 872.

16 For some reviews, see: (a) P. A. Bartlett, in Asymmetric Synthesis, ed. J. D. Morrison, Academic Press, New York, 1984, Vol. 3, pp. 411-449. (b) G. Cardillo and M. Orena., Tetrahedron, 1990, 46, 3321. (c) K. E. Harding and T. H. Tiner, in Comprehensive Organic Synthesis, Ed. B. M. Trost and I. Fleming, Pergamon Press, Oxford, 1991, Vol. 4, ch. 1.9, pp. 363-421. (d) G. Cardillo, and M. Orena, in Stereoselective Synthesis. Methods of Organic Chemistry (Houben-Weyl), Ed. G. Helmchen, R. W. Hoffmann, J. Mulzer, E. Schauman, Georg Thime Verlag, Stuttgart, 1995, vol. E21e, p. 4698. (e) M. Orena, in Stereoselective Synthesis. Methods of Organic Chemistry (Houben-Weyl), Ed. G. Helmchen, R. W. Hoffmann, J. Mulzer, E. Schauman, Georg Thime Verlag, Stuttgart, 1995, vol. E21e, p. 5351. ( $f$ ) M. Frederickson and R. Grigg, Org. Prep. Proced. Int., 1997, 29, 33. (g) M. Frederickson and R. Grigg, Org. Prep. Proced. Int., 1997, 29, 63. (h) S. Robin, and G. Rousseau, Tetrahedron 1998, 54, 13681. (i) (j) C. K. Tan, L. Zhou, and Y.-Y. Yeung, Synlett, 2011, 1335. (k) S. A. Snyder, D. S. Treitler and A. P. Brucks, Aldrichimica Acta, 2011, 44, 27. (l) C. K. Tan and Y.-Y. Yeung, Chem. Commun., 2013, 49, 7985. (m) C. B. Tripathi and S. Mukherjee, Synlett, 2014, 25, 163.

17 G. Rousseau and F. Homsi, Chem. Soc. Rev., 1997, 26, 453.

18 (a) S. Jew, S. Terashima and K. Koga, Tetrahedron, 1979, 35, 2345. (b) C. Ko, R. P. Hsung, Z. F. Al-Rashid, J. B. Feltenberger, T. Lu, J.-H. Yang, Y. Wei, and C. A. Zificsak, Org. Lett., 2007, 9, 4459 
19 R. Pedrosa, C. Andrés, R. Arias, P. Mendiguchía and J. Nieto, J. Org. Chem., 2006, 71, 2424.

20 R. Pedrosa, C. Andrés, P. Mendiguchía and J. Nieto, J. Org. Chem., 2006, 71, 5388.

21 R. Pedrosa, C. Andrés, P. Mendiguchía and J. Nieto, J. Org. Chem., 2006, 71, 8854.

22 For some reviews on selenocyclofunctionalization reactions, see: (a) M. Tiecco, Top. Curr. Chem. Modern Developments in Organic Synthesis. Ed. T. Wirth, Springer, Heidelberg, 2000; pp. 7-54. (b) N. Petragnani, H. A. Stefani and C. J. Valduga, Tetrahedron, 2001, 57, 1411. (c) S. Ranganathan, K. M. Muraleedharan, N. K. Vais. and N. Jayaraman, Tetrahedron, 2004, 60, 5273. (d) C. Santi and S. Santoro in Organoselenium Chemistry: Synthesis and Reactions, Ed. T. Wirth, Wiley-VCH, Weinheim, 2012, pp. 1-38.

23 Chiral perhydro-1,3-benzoxazines derived from (-)-8-aminomenthol are useful chiral templates in the synthesis of enantiopure nitrogen heterocyclic compounds by different cyclization processes. (a) R. Pedrosa, C. Andrés, J. Nieto, J. Org. Chem., 2000, 65, 831. (b) R. Pedrosa, C. Andrés and J. Nieto, J. Org. Chem,. 2002, 67, 782. (c) R. Pedrosa, C. Andrés, J. Nieto, S. del Pozo, J. Org Chem., 2003, 68, 4923. (d) R. Pedrosa, C. Andrés, A. GutiérrezLoriente, J. Nieto, Eur. J. Org. Chem., 2005, 2449. (e) R. Pedrosa, C. Andrés, J. Nieto, S. del Pozo, J. Org. Chem., 2005, 70, 1408. (f) R. Pedrosa, C. Andrés, L. Martín, J. Nieto, C. Rosón, J. Org. Chem., 2005, 70, 4332

24 R. Pedrosa, C. Andrés, C. D. Rosón and M. Vicente, J. Org. Chem., 2003, 68, 1852.

25 C. Andrés, I. González, J. Nieto, C. D. Rosón, Tetrahedron, 2009, 65, 9736.

26 R. Pedrosa, C. Andrés, J. M. Iglesias and A. Pérez-Encabo, J. Am. Chem. Soc., 2001, 123, 1817

27 R. Pedrosa, C. Andrés, L de las Heras and J. Nieto, Org. Lett., 2002, 4, 2513.

28 (a) E. L. Eliel and X.-C. He, Tetrahedron, 1987, 43, 4979. (b) E. L. Eliel and X.-C. He, J. Org. Chem., 1990, 55, 2114.

29 R. Pedrosa, C. Andrés, A. Maestro, A. and J. Nieto, Synthesis, 2003, 1457.

30 Vukicevic, R.; Konstantinovic, S.; Mihailovic, M. L. Tetrahedron 1991, 47, 859.

31 (a) M. Tiecco, L. Testaferri, M. Tingoli, D. Chianelli, D. Bartoli, Tetrahedron, 1988, 44, 2261. (b) M. Tingoli, M. Tiecco, L. Testaferri, A. Temperini, J. Chem. Soc., Chem. Commun., 1994, 1883. (c) M. Tingoli, L. Testaferri, A. Temperini, M. Tiecco, J. Org. Chem., 1996, 61, 7085.

32 M. Tiecco, L. Testaferri, C. Santi, C. Tomassini, F. Marini, L. Bagnoli, A. Temperini, Eur. J. Org. Chem., 2000, 3451 and references therein.

33 D. L. J. Clive, G. J. Chittattu, V. Farina, W. A. Kiel, S. M. Menchen, C. G. Russell, A. Singh, C. K. Wong, N. J. Curtis, J. Am. Chem. Soc., 1980, 102, 4438.

34 C. Andrés, M. García-Valverde, J. Nieto, R. Pedrosa, J. Org. Chem., 1999, 64, 5230.

35 C. Andrés, J. Nieto, R. Pedrosa, M. Vicente, J. Org. Chem., 1998, 63, 8570. 